\title{
Japanese Buddhism and Ireland
}

Laurence Cox and John Ó Laoidh

National University of Ireland Maynooth, Maynooth, Ireland.

laurence.cox@mu.ie

johnolaoidh@outlook.com

Published in Journal of Religion in Japan 11/1, 2021: this is the pre-review submission.

\begin{abstract}
This article argues that there is no single relationship between Japanese Buddhism and Ireland, but rather a series of changing relationships mediated by different world-system contexts between one island and another (peripheral and post-colonial) one: as ethnographic information, as cultural influence and as religious practice. The process has a long history, stretching back to the Irish reception of Jesuit and traveller's accounts, and then made concrete by early intermediaries like Lafcadio Hearn / Koizumi Yakumo and Charles Pfoundes. WB Yeats helped to give Japanese Buddhism a significant place in Irish culture, notably in poetry. From the 1960s and 1970s Japanese Buddhists started to settle in Ireland and Japanese Buddhism began to be practiced; both are now an established part of the Irish religious landscape. The article sketches this history together with the present situation of Japanese Buddhism in Ireland.
\end{abstract}

Keywords: Japanese Buddhism, western Buddhism, Ireland, religious studies, migration, cultural reception 
Acknowledgements: With grateful thanks to Daniel Breen, Ian Cudmore, Philip Horan, Myozan Kodo, Lillis Ó Laoire, Sinéad Lynch, Mary Laheen, Beth O’Halloran, Margery Reynolds, Saito Shoichi and anonymous respondents to our interviews and survey. 


\section{Introduction}

Japan and Ireland are not only both islands, but are both peripheral to larger landmasses with their own religious points of origin (for Japanese Buddhists, India and China; for Irish Catholics, the Middle East and Rome). Both can thus be seen as what the Buddhist vinaya calls "border regions" (Cox and Griffin 2009). The genealogies of East Asian Buddhism are populated by monks who made that journey from periphery to core and returned until their country became a Buddhist centre, in many ways deriving its Buddhist identity from those figures who journeyed from the periphery.

Just as the Chinese Buddhist Xuanzang journeyed to Buddhism's South Asian homelands and back, so in turn it was Japan's peripheral status (in Buddhist terms) to continental China secured the enduring prestige of returned pilgrims such as Dōgen Zenji (Jp. 道元禅師). As Buswell (2005) has shown for Korea and East Asian Buddhism more generally, the idea of an active core and a passive periphery is problematic: and Japanese Buddhism (like Irish Catholicism) would in time assert itself as a religious homeland, sending missionaries not only to the Japanese diaspora but in the context of the colonisation of Korea - and being seen by Irish people as itself a wellspring of Buddhism.

If dominant western societies such as the US or UK often received Buddhism through processes largely shaped by their own cultural perceptions and interests, postcolonial societies such as Ireland typically lack the power to remake Buddhism in their "own" (highly contested) image. Irish culture is thus a border region: both a second-hand recipient of developments in more powerful western societies and involved in a multiplicity of dialogues at a distance with Japanese Buddhism.

Border regions can be active sites of religious creation; but in complex ways. In the late $19^{\text {th }}$ and early $20^{\text {th }}$ centuries, the period of 'high imperialism', both Ireland and Japan came (differently and in different tempos) to assert new discourses, of essential 'Japanese' or 'Irish' cultures, in reaction to the powerful discourses from the British, American and other metropolitan centres; religion and culture played an important part in this dialogue, which shaped much of the early Irish reception of Japanese Buddhism.

However, world-systems theory has convincingly argued both that the distinction between core and peripheral countries is too simple, and that there is no given national essence, whether produced through the dynamics of colonialism and later dependency or predating these. Instead, it highlights the relationships that link different spaces within different kinds of global context (Hall 2000: 11); and this analysis enables a better historical understanding of the changing kinds of relationship between Japanese Buddhism and Ireland over the centuries.

In the $16^{\text {th }}$ and $17^{\text {th }}$ centuries, capitalist trade and European wars of religion created a context for ethnographic information on Japanese Buddhism to percolate through to Ireland. The Meiji era, European colonialism in Asia, and the cultural nationalism of Ireland's Gaelic Revival, would create a very different context for occasional individual encounters and intensified cultural exchange and dialogue. From the 1970s in particular, Ireland's cultural reopening, and capitalist globalisation, have seen Japanese Buddhist migrants in Ireland and Irish converts to Japanese Buddhism. However in each of these periods, the multiple relationships between different aspects of Irish and Japanese society have in turn generated several largely separate "lives" of Japanese Buddhism in Ireland.

In line with this diversity of relationships, this article draws on multiple forms of research, including reception history, biographical research and digital archives. Phone and email interviews were carried out with people involved in Japanese Buddhism, and Principal Saito 
Shoichi kindly facilitated an online survey with members of the Japanese community. We are very grateful to those who took part in these discussions.

\section{Early reception and cultural contacts}

\section{Early modern reception history}

Ireland's peripheral situation in relation to European culture, and Japan's in relation to Asian Buddhism, naturally shaped early reception. As Ireland - and its diasporas - became briefly important in the re-Christianisation of Europe during the Age of Migrations, some Irish people became aware of Buddhism from the $6^{\text {th }}$ or $7^{\text {th }}$ centuries CE, via the writings of the Church Fathers, but representing what Alexander the Great and his successor kingdoms had encountered before Buddhism had arrived in Japan (Cox 2013, ch 2).

In the $13^{\text {th }}$ and $14^{\text {th }}$ centuries European travellers to the Khanates wrote accounts of their journeys, which circulated as far as Ireland. None reached Japan, which remained beyond Mongol rule, though Irish readers could know Marco Polo's comment that Japanese "idols" (with no distinction between what we now call Buddhism, Confucianism and Shinto) were the same as the Chinese, but that "the works of these idols are so manifold and of such devilish contrivance that it is not proper to speak of them" (1968: 209-10).

Thus knowledge of Japanese Buddhism did not reach Ireland until the European capitalist expansion of the $16^{\text {th }}$ and $17^{\text {th }}$ centuries engaged with both islands, bringing western sailors, traders, missionaries and others to Japan. For Ireland, the period saw Tudor reconquest and the Wars of the Three Kingdoms, the end of the Irish-speaking nobility (the traditional patrons of learning), the proscription of Catholicism, and extensive land seizures by Englishspeaking Protestants from Britain, generating a significant student, religious, military and trading Irish diaspora across Continental Europe.

The result was two distinct if overlapping Irish circuits of knowledge: a Catholic one, largely underground in Ireland and allied to Catholic forces in Europe, and a Protestant one, allied to English imperial and trading efforts internationally - on a multi-lingual island where not only Irish and English, but Latin and French as well as other European languages were significant in publishing and reading. These shaped the reception of the many European travellers' accounts of Asia and elsewhere, published independently or in compilations. In French, English or Latin, these were read in Ireland - in expensive editions bought by Protestant divines, in subscription format, as entertainment for the educated and in cheap pirated editions (Cox 2013, ch 2).

Books attested in Ireland include multiple copies of Hakluyt's Principal navigations, voiages, traffiques and discoueries of the English nation (including Japan from its 1600 edition on), Samuel Purchas' subsequent collections, François Caron's A true description of the mighty kingdoms of Japan \& Siam (1645, English editions 1663 and 1671) and Bernard Picart's Cérémonies et coutumes religieuses de tous les peuples du monde (1739, English edition 1741). By 1747, when Thomas Astley published his New general collection of voyages and travels, Tokugawa Japan was closed to the world and he did not include it.

Largely separately, accounts of the life of St Francis Xavier and Jesuit histories of their Japanese mission (Fujikawa 2017) probably circulated among clandestine Jesuit schools in Ireland, and certainly among the Irish Catholic diaspora on the Continent. Irish religious in Italy and Spain may well have been aware of the Tensho embassy to the Roman curia: an account was published in Latin in Macao in 1590. 
Irish knowledge of Japanese Buddhism in this period was thus shaped particularly by the intense pressures of the Wars of Religion and an understanding, shared by Catholics and Protestants alike, of Asian religions as "idolatrous". As with Marco Polo, an identification of the specific characteristics of Japanese Buddhism as distinct from Chinese, or of Japanese Buddhism as distinct from other Japanese religions (as we now see them) would have been a rare achievement, to say nothing of identifying different Japanese Buddhist sects from the viewpoint of a Europe that assumed "cuius regio eius religio", that a realm homogenously followed its ruler's denominational affiliation.

Reception in this period tended towards the dramatic, such as the spectacular engraving of the "Temple of Ten Thousand Idols in Japan" in the English edition of Picart, or Caron's accusation that Japanese Buddhist priests practiced sodomy and employed prostitutes (Offermans 2005: 28). One particularly widely-circulated account was that of the 1597 "glorious martyrdom of the Cross" suffered by six Franciscans at Nagasaki and publicised by the order worldwide as part of its polemic against the Jesuits (Vu Thanh 2017). Despite these frames, some information about Japanese Buddhism as observed by outsiders did become available in Ireland and to the Irish abroad in this period.

\section{The first Irish / Japanese Buddhists: Pfoundes and Hearne}

The 'high colonialism' of the late $19^{\text {th }}$ and early $20^{\text {th }}$ centuries saw the forcible 'opening' of Japan and the Meiji restoration; in Ireland, from the Great Famine of 1845-49 on emigration reached massive heights, with perhaps $40 \%$ of those born in Ireland living elsewhere by 1890. These created new relationships to an intensification of global capitalist and imperial relationships in many ways; new kinds of popular nationalist mobilisation developed (in very different ways) on both islands, not least in response to the fact of empire. Religion, and culture more generally, played an important role here.

The British empire, capitalist trade and Catholic and Protestant missionary work drew large numbers of Irish people to Asia, including Japan, while the increased centrality of religion as ethno-political identifier in Ireland meant that active interest in other religions carried substantial social and economic, as well as legal, risks. Thus up until the 1990s, most Irish people actively engaging with Japanese Buddhism did so outside the country; indeed the first Buddhist mission to the west was led by one such Irishman (Bocking et al. 2014).

Capt. Charles Pfoundes (1840-1907) was born to Irish Anglican parents bankrupted during the Famine and emigrated to Australia where he joined the colonial navy, followed by the Siamese navy, and travelled to Japan in 1863. Here he became an interpreter, cultural and trade broker and wrote newspaper pieces on Buddhism and other subjects, taking the punning Japanese name Omoie Tetszunotszuke. A decade after returning to Europe in 1876, he flirted briefly with Theosophy but soon realised the differences between the Japanese Buddhism he knew first-hand and the Theosophists" "Esoteric Buddhism".

In 1889 Pfoundes joined forces with the Kaigai senkyō kai (Buddhist Propagation Society), a modernising Nishi Honganji-based initiative to "propagate Japanese Buddhism abroad" on a non-sectarian basis. From October 1889 to November 1892 he ran the London branch of the BPS with great energy, the first such mission to the west. This mission eventually collapsed and Pfoundes returned to Japan, where he remained an active Buddhist connected to various sects until his death in 1907: for example, playing a role in a fire ceremony held in support of the Japanese war effort in 1904-05.This London mission was to the capital of a state which included Ireland and a city which was central to much Irish cultural activity; we only know of Pfoundes visiting Ireland briefly, for family reasons, during this period (Bocking 2018). His 
travels, and intercultural connections, are typical of Irish engagement in Japanese Buddhism until the 1990s boom.

On January $11^{\text {th }}, 1891$, Pfoundes took the stage at a National Secular Society hall in Battersea, London, to give a "Buddhist sermon", accompanied by "a Buddhist Priest in his robes" (National Reformer 4 Jan 1891, p. 15). On February 22 ${ }^{\text {nd }}$, two Nishi Honganji priests performed a Buddhist ritual at the Musée Guimet in Paris ("Parisian Topics", The Standard, 23 Feb 1891, p. 5). In all likelihood these were the same individuals: we have no record of any visit to Ireland, but it is not impossible. The same is true for three Japanese Buddhist specialists who studied with Max Müller at Oxford: Junjiro Takakusu, Kasahara Kenju and the Higashi Honganji priest Nanjo Bunju.

In Japan, a more important figure was the Irish writer Lafcadio Hearn, who lived in Japan from 1890 until his death in 1904. Hearn - who influenced Yeats (below) - celebrated "old Japan" at the height of the initial Meiji celebration of western modernity, contributing to the development of a literary form of cultural nationalism as a significant export, "answering back" to Empire. Tweed (2000) discusses Hearn at length as a Buddhist sympathiser; Kenneth Rexroth edited his Buddhist writings (1977).

In Tweed's terms, both Pfoundes and Yeats had a romantic relationship to Buddhism, mediated by commitment to a specific Asian culture; in some ways the Japanese element of their Buddhism thus appears as central. Like Pfoundes, Hearn was non-sectarian, unusually interested in Tendai as well as (like Pfoundes) Shingon and for that matter Shinto. Hearn's books emphasise a vision of popular Buddhism as represented in folklore and rituals, as well as impermanence, illusion and the need to suppress desire. In his first encounter with a Buddhist priest, he stated that he made offerings because "I revere the beauty of [the Buddha's] teachings, and the faith of those who follow it" (cited in Murray 1993: 124). While Pfoundes made his living as a cultural intermediary, Hearn "went native" more thoroughly, marrying a Japanese woman and taking Japanese citizenship as Koizumi Yakumo, making daily offerings to Buddhist deities (Cott 1991: 315) and being given a Buddhist funeral.

\section{Laffère, Dhammaloka, Butler Burke}

Other Irish Buddhists of the period engaged with Japanese Buddhism but not primarily with Japan. For example, Dubliner Richard Laffère appears on the 1904-6 subscription list for the Light of Dharma, the magazine of the Jodo Shin mission to San Francisco (Tweed thanks). Laffère received two copies of each issue, one probably being sent to his Singapore address, where he worked as a surveyor.

In July 1905, Laffère appears as the Theravada Buddhist monk U Vara, seeking to found a Buddhist mission in Penang with another Irish Buddhist monk, U Dhammaloka (Turner et al. 2020: 122-3). Vara, who died in 1909, had probably been ordained by Dhammaloka in his Singapore mission: one such ordination ceremony included the Japanese Buddhist priest Rev. Ocha. Ocha is a mystery, including his sectarian identification (Turner et al. 2020: 116): he set up a Japanese Buddhist mission at 65 Sarangoon Rd in 1899, contemporaneous with the Nishi Honganji missions to California, and collaborated closely with Dhammaloka, including on a 1904 multi-ethnic Wesak celebration including Dhammaloka's mission, a Sinhalesesponsored feast at the Chinese Buddhist temple and Buddhists across the city illuminating their homes.

Dhammaloka (1856-1913?), however, is well-attested (Turner et al. 2020). A Dublin-born sailor, migrant worker and eventually Buddhist monk, he was a celebrity preacher in Burma and active in the pan-Asian Buddhist revival between 1900 and 1913, including Singapore, 
Siam, Ceylon, India and Japan. Dhammaloka was particularly concerned to combat the cultural impact of colonialism through resistance to Christian missionaries and temperance activity and found himself repeatedly confronting colonial authorities: he had at least five pseudonyms, was tried for sedition at least once, put under police and intelligence surveillance, faked his own death and eventually disappeared.

Dhammaloka had probably visited Japan as a trans-Pacific sailor before becoming a Buddhist: in 1902-3 he spent several months in Japan, where a follow-up to the 1893 World's Parliament of Religions had been mooted. Although this event did not take place, Dhammaloka spoke at the foundation of the Jodo Shinshu Bankoku bukkyo seinen rengokai, the International Young Men's Buddhist Association, a successor to the Kaigai senkyo kai. After the IYMBA's collapse in 1903, Dhammaloka continued its programme of Buddhist revival across Asia.

While in Japan Dhammaloka stayed with the Pure Land priest Oda Tokunō and at the Shingon Mejiro Sōen with Shaku Unshō. He also addressed the "East Asian Buddhist Association" at Oda's invitation and gave a major interview to the Nipon newspaper, serialised over 9 issues. In this he criticised Japanese priests for drinking sake and those who married secretly (by contrast, he said, with the Honganji sects where marriage was open). "I came [to Japan] to conduct a comparative study of Southern Buddhism and Northern Buddhism, that is Hinayana and Mahayana... [W] hen I came here, it was not at all to belong to this or that particular sect. It is just to study Mahayana Buddhism..." This did not, however, prevent him criticising Mejiro's Shingon as "not the Buddhist doctrine but a lump of superstitious cult".

Dhammaloka and Pfoundes were unusual in their detailed knowledge of Japanese Buddhist sects. Even sympathetic Irish people who had not been to Asia - then as now - might make little distinction between sects, different national Buddhisms or even different Asian religions. For example, the Irish-American Vivian Butler Burke, who founded Ireland's first Buddhist centre (perhaps 1927 - 1936: Cox 2014) at her Dublin home, identified Mahayana bodhisattvas with Irish myths: "in one of our old pagan tales one of the Shining Ones, coming to guide a hero, says to him: 'I am a messenger from beyond the world, and I come to your help because your heart ever burns to come to the help of others." ("An Irish Gael" 1928: 6). She owned a number of items of Japanese art, notably an Amida Nyorai statue modelled on the Kamakura Daibutsu. It is likely that participants at the first public Buddhist events in Ireland assembled before this statue.

\section{Irish missionaries and Japanese Buddhism}

A limited amount of knowledge of Japanese Buddhism returned to Ireland via missionaries. There may have been Irish participants in the Jesuit or Franciscan missions to Muromachi Japan; and Irish missionaries, Protestant and Catholic, travelled to Japan after the Meiji restoration. However the tendency for Irish Catholic missionaries in particular was to dismiss the cultures they encountered as generically "idolatrous" (Cox 2013: ch 3).

In the late $19^{\text {th }}$ and early $20^{\text {th }}$ century, this ignorance was reinforced via funding drives in a provincial and poorly-educated Ireland, focussing on "saving heathen souls". Irish enthusiasm for the cult of St Francis Xavier, presenting a picture several centuries out of date, did not advance understanding. Even among Catholic intellectuals, as evidenced by book collections or the writings of philosopher John Howley - a homogenising view of Asian Buddhism prevailed up to the 1950s (Cox 2013: ch 6). 
Later in the $20^{\text {th }}$ century, some Irish Catholics outside the country responded to the winds that led to Vatican II, notably dialogue with Japanese Zen. The Irish Jesuit William Johnston, professor of religion at Sophia University, Tokyo, saw engagement with Zen as fundamental to recovering the Christian contemplative tradition (eg Johnston 1977), while theologian Joseph O'Leary (1999) engaged substantially with Buddhist-Christian dialogue. Until John Paul II, and Cardinal Ratzinger at the Congregation for the Defence of the Faith, dampened this enthusiasm, Japanese Buddhism acquired a specific, and positive, meaning for some Irish Catholic intellectuals in the shape of Zen meditation.

\section{The cultural reception of Japanese Buddhism within Ireland}

\section{Helen Waddell and WB Yeats}

The combination of Europe's colonial relationship to Asia, and Ireland's peripheral relationship to Europe, meant that occasional close and sympathetic Irish religious encounters with Japanese Buddhisms in this period were often outweighed by vague generalisations on Japan, Buddhism or "Asia". Representations within Irish culture were similarly mixed, often generalising "Japanese Buddhism" or seeing it as epitomised by a homogenous "Zen".

The main impulse from Japanese Buddhism in this period would come through literature, starting with a second-generation product of Irish missions, the novelist Helen Waddell (1889-1965). Waddell's father Hugh was sent to Japan in 1874 as a Presbyterian missionary, but broke with his church for being too severe on a native pastor, spoke good Japanese and had pretensions as a Chinese scholar (Cox 2013: 139). Helen grew up in Japan until the family's return to Belfast in 1900 (Burleigh 2005: 1-2).

Here Waddell drew on her childhood familiarity with everyday Buddhism in various pieces, notably her play The spoiled Buddha, which played at Belfast Opera House in 1915. This presents Buddhist temple statues coming to life to argue morality, with the ultimate revelation that the Buddha has been silently in love with Kwannon all along. In this folk art approach, Buddhism offers a stock of characters, albeit treated with great affection.

However the leading early culture importer of Japanese Buddhism to Ireland was the Nobel prize-winning poet, playwright and Senator WB Yeats. As a student in 1884, Yeats cofounded the Trinity College-based Hermetic Society 'to promote the study of Oriental religions and theosophy generally'(Guinness 2004:21), He had read A. P. Sinnett's Esoteric Buddhism which led to the formation of a Theosophical milieu in Ireland (Cox 2013:178). Though the Irish branch of Theosophy joined the "western" split towards an emphasis on esoteric Christianity, western occultism and an interest in Celtic myth, Yeats remained powerfully affected by Japanese Buddhism in particular.

His interest in Japan grew through correspondence with Hearn, who interpreted Asian Buddhism through Anglo-Irish eyes, adapting Yeats' strategy of disidentifying with establishment religion and exalting peasant religion to the circumstances of Japan and Burma (Cox 2013:124). In 1903 Yeats met the poet, teacher of English literature and Hearn enthusiast Yone Noguchi in London in 1903 (Suhr-Sytsma 2010:249-250). Around 1913, Yeats encountered Noh theatre through the work of his friend Ezra Pound who was working on the papers of Buddhist sympathiser Ernest Fenellosa. Yeats thought that Noh received 'its philosophy and its final shape perhaps from priests of a contemplative school of Buddhism' (ie Zen), speaking of 'a deep of the mind that had hitherto been too subtle for our habitation' and concluding 'It is now time to copy the East and live deliberately' (1916) (Cox 2013:180). 
This Japanese influence on Yeats cannot be overstated and was "paradoxically disproportionate to his first-hand knowledge" (Hayley 1988:43). Despite flirting in 1919 with the idea of an academic post in Tokyo, he never set foot in Japan but kept up a decades-long correspondence with Noguchi on topics such as Hiroshige and Japanese painting (SuhrSytsma 2010:250).

Around 1926, Yeats was given the first volume of DT Suzuki's Zen essays by Prof. Yano of Tokyo Metropolitan University. He subsequently received copies of Suzuki's Eastern Buddhist twice yearly until his death (Doherty 1983). Suzuki's Zen Buddhism and its influence on Eastern culture may have introduced a positive sense of sunyata in Yeats' 'The Statues' (Shiro 1972; Cox 2013:181) - but like other works of Suzuki's underlined the equation between Zen, Japan and "the East".

Yeats' response to Japanese Buddhism remained fundamentally aesthetic rather than practical, within a dialogue between cultural nationalisms in which he and Suzuki were key figures: with Hearn he exemplifies Tweed's romantic interest in Buddhism as expression of what he understood as Japanese culture, while in his turn contributing powerfully to codifying the new sense of what was essentially Irish: another Nobel prize-winner in yet another colonial context (Rabindranath Tagore) saw Yeats as 'confluent with the ancient poetic tradition of Ireland' (Lennon 2003: 154).

Yeats' fascination with 'the East' informed his construction of an 'authentic', pre-colonial Gaelic identity (Lennon 2003:129), writing of Irish peasants "had they not lived in Asia until the Battle of the Boyne?" (cited in Murphy 2011: 79). The supposed essence of Irishness could thus be equated with Zen (identified with Japan, identified with Asia), both contrasted to western modernity in a powerful transnational literary dialogue: repeating the Orientalist gesture in an endless hall of mirrors.

\section{Celtic and Japanese hermit-poets?}

Poetry has long been one of the highest-status forms of literature within Ireland (as in Japan); from this period on, it became a key location for the articulation of national identity parallel to this implicit or explicit dialogue with Japanese Buddhism. In the later $19^{\text {th }}$ and early $20^{\text {th }}$ century, both these peripheral islands saw powerful nationalisms articulated against dominant British or European colonialism, asserting - but also exporting - literary notions of the nation's unique essence with strong mystical overtones; in the Irish case, articulating a 'Celticism' (McCormack 1985) or 'Celticity' (Gierek 2011) grounded variously in the pagan or early Christian past.

Another Irish Nobel laureate, Séamus Heaney, identified a 'Japanese effect' in Irish poetry (Heaney 2002). The anthology Our Shared Japan (2007) 'makes clear the staggering number of Irish poets since Yeats - eighty-five between its covers - who have been influenced by encounters with Japan and its artistic traditions' (Suhr-Sytsma 2010:245). In a specific comparison to Japanese Buddhist poetry, Heaney references the early Irish hermits and monastic scribes who wrote on the margins of illuminated manuscripts as 'people whose response to a detail of the world was a response to its whole mystery'(2000).

Importantly for later reception of Japanese poetry, early Irish nature poetry was understood as primarily written by monks, understood as living a hermit-like existence similar to the literary conceits of Zen poetry. However historically accurate, modern Irish readers imagined solitary meditative monks responding to nature in ways unmediated by cultural accretions while (of course) simultaneously being quintessentially Celtic, or Japanese. Timing is significant here: Sims-Williams's work on the invention of 'Celtic nature poetry' (1996: 97) 
shows that the idea of 'Celtic literature' hardly existed before 1854, the year of the Convention of Kanagawa ${ }^{1}$.

The attraction, for Irish poets, was to what they understood as simplicity of expression and a pure state of being in nature. The Japanese effect in Irish poetry, wrote Heaney, entailed 'devotion to succinctness' and a 'formal concision'. The affinity that Heaney here perceived between a "Celtic" purity of expression and the form of Japanese Manyoshu and Haiku poetry, had long roots. Nearly a century earlier, the influential Celtic philologist Kuno Meyer commented

"Like the Japanese, the Celts were always quick to take an artistic hint; they avoid the obvious and the commonplace; the half-said thing to them is dearest." (Meyer 1911).

At the Japanese end of this dialogue, D. T. Suzuki too 'relied heavily on the categories of nineteenth-century orientalism' (Faure 1993: 64) in his portrayal of Japanese poetry as suffused with a spirit of Zen which was both perfected by the Japanese people and a pure expression of the universal human condition (e.g. Suzuki 1959).

Irish Orientalism became simultaneously "a way to participate in empire and a way to deny it" (Lennon 2003:157), enabling both collusion and decolonizing impulses as it conjured up "The ancient and absent Celtic as a means to mirror the living and present Orient" (Lennon 2003:131) exemplified by Japanese Zen. At the same time, as Cristina Rocha has argued for Brazil, Zen could offer Irish intellectuals an avenue to cosmopolitanism.

\section{Contemporary poets}

Suhr-Sytsma (2010: 246) draws a distinction between two types of contemporary Irish poet engaging with Japan and Japanese forms. Some are already established poets who, if they have visited Japan, have done so as 'cultural diplomats', often with bursaries and arts council funding. This includes poets like Derek Mahon, Michael Longley, and Ciaran Carson whose 'encounters with Japan are often strongly mediated by prior exposure to Japanese aesthetic forms' and who have 'fashioned memorable poems out of Japanese materials' (ibid). Thus, for example, a visit to Kyoto's Ryoan-ji Temple served as inspiration for Michael Longley's "A Gift of Boxes" and "A Pair of Shoes" (256). The work of Eavan Boland and Nuala Ní Domhnaill also shows Japanese influences.

Suhr-Sytsma's second group consists of younger writers such as Sinéad Morrisey and Joseph Woods who worked and lived for extended periods in Japan 'negotiating cultural dislocation and estrangement'; these younger poets' 'more extended sojourns in Japan have led them away from this vision of an essentially aesthetic Japanese culture' which is 'not purely imaginary' (Suhr-Sytsma 2010: 246).

Irish poets acknowledging a specific interest in Japanese Zen include Medhbh McGuckian (who references William Johnston), Paula Meehan, Paul Muldoon, Caitríona Ní Chléirchín, Micheál Ó Cuaig, Seán Ó Curraoin and Gabriel Rosenstock. While Denvir (1988) identifies Zen influences in the Irish language poetry of Tomás Mac Síomóin or Gabriel Rosenstock as a break with tradition, he argues for the use of the haikú (Gaelicized spelling) to express 'sudden explosions of deepfelt emotion, flashes of intuition or insight' as being 'the legitimate voice of the Irish poetic tradition in the contemporary situation' (Denvir 1988:54), repeating the gesture articulated by Yeats and Suzuki.

\footnotetext{
${ }^{1}$ The romantic chivalric culture of the medieval Japanese warrior, Bushīdo was also being constructed in retrospect in Japan at this time (Benesch, 2014).
} 
The haiku form in particular has become firmly established within Irish writing, with an Irish Haiku Society. Gabriel Rosenstock (b.1949), a lineage holder of Celtic Buddhism, has published prolifically on the subject of the haiku as well as composing in this form both in Irish and English. His 'Chogyam Trungpa: One Hundred Haiku' (2014), originally written in Irish, was later translated into Japanese, bringing us into an explicitly Buddhist as well as Japanese mode.

Irish language scholar, and Nichiren Buddhist, Gary Bannister has published a book of Zen koans in both Irish and English (Bannister 2018). Finally, Soto Zen priest Ian Kilroy (Myozan Kodo) has published several collections of English-language Zen poetry, not least 'Songs from the Denkoroku', inspired by Keizan's classic 'Record of Transmitting the Light'.

From these specifically Japanese literary forms to another defining Irish one: in 2001 leading singer-songwriter Luka Bloom released 'Soshin', inspired by Irish-American Buddhist Maura O'Halloran (below). The contemporary Irish-language group Kíla called their 2010 album Soisin after her, while their 2002 Monkey! soundtrack references western reception of Japanese versions of the Chinese folk stories of the Monkey King Sun Wukong, said to have assisted the Chinese Buddhist pilgrim Xuanzang on his journey to India in search of Buddhist sūtras ${ }^{2}$.

From Yeats to the present, then, areas of Irish cultural production which help define 'Irish national identity' - poetry, music, Irish language writing - have been shaped by this dialogue with Japanese Buddhism.

\section{Other arts}

This encounter fits within a wider, if shallower, cultural encounter. As early as the 1853 Irish Industrial Exhibition, the Royal Asiatic Society exhibited a "Japanese joss-house, used by the people for the reception of Buddhist idols in their domestic worship", while J Gallagher of the naval ship HMS Arrogant lent "a collection of Chinese and Japanese curiosities" (Sproule 1854: 475). Colonial-era Irish museums collected Japanese items, both within an Orientalising or "world religions" frame and for the purposes of developing Irish design. Some items were also gifted by returning Irish diplomats, sailors etc. or their descendants.

Dublin museums thus came to showcase various elements of Japanese Buddhist culture. The National Museum holds Albert Bender's collection of Far Eastern Art, opened in 1934 and including a fine collection of ukiyo-e prints (below). The Chester Beatty collection, including religious items in particular (such as a wooden pagoda from Nara), has been on public view since 1968. For much of the $20^{\text {th }}$ century, the Dalgan Park headquarters of the Columban missionary order also had a room dedicated to Japanese material ${ }^{3}$.

In this context, occasional visual artists echoed the more sustained literary encounter with Japanese Buddhism. The influx of Japanese woodblock prints in the later nineteenth century, often used as packing for goods like porcelain (and reused as wrapping paper) exerted a powerful influence on the course of western art (Ives 1974: 12,13), notably via the French Impressionists and post-impressionists. In this context Irish painter Roderick O'Conor (1860-

\footnotetext{
${ }^{2}$ This particular wheel has come full circle: Xuanzang's seventh century translation of the Heart Sūtra is chanted (in Japanese pronunciation) on a daily basis in Zen dojos around Ireland.

${ }^{3}$ However media reception of Japanese Buddhism remained very limited until recently : for example, in 1910 the Sunday Independent covered Zuicho Tachibana's journey across Central Asia in search of Buddhist manuscripts (Mar 27 1910: p. 8), and in 1933 the Meath Chronicle reported a Japanese Buddhist becoming a Jesuit (Apr 15 1933: 8).
} 
1940) shows the influence of Japanese art in works such as 'Breton Peasant Woman Knitting' (1893), in turn influenced by Suzuki Harunobu (1725-1770) via Edouard Vuillard's (18681940) 'Seamstress', which echoes Harunobu's 'Youth Playing a Drum' (c.1768). The successful execution of O'Conor's figures of Breton women knitting and sewing, arguably some of his most successful works, was due in large part to his ability to capture $b y \bar{o}-j \bar{o}$-shin (Jp.本常心), 'everyday mind,' a Zen concept which found its way into French art at that time.

A different kind of dialogue is represented by the Japanese Gardens in Kildare, laid out by Tassa and Minoru Eida in 1906-10 for Col. Hall Walker, who had visited Japan. These present a rather idiosyncratic version of a "journey of life", designed to express both "East" and "West".

It would not be until the 1970s, after the growth of the counterculture, that Irish visual arts began to reference Japanese Buddhism directly. For example, the title of painter Tim Goulding's (b.1945) 2008 exhibition Floating World is a direct translation of the Japanese ukiyo (浮世), the transient phenomenal world of geishas, courtesans, samurai, noh drama actors, libertines and sumo wrestlers which was the most common subject matter of the Japanese woodblock prints collected by Bender and others. Its homophone Ukiyo (Jp. 憂き 世) which means 'Sorrowful World,' itself a direct reference to the Shaba-sekai (Jp. 娑婆世界) or 'Sahā World' of suffering and endless rebirth which Buddhists seek liberation from. Campbell (2008:1) notes Goulding's 'awareness of Japanese philosophy and art and also ... a non- attached or ethereal state' in his art.

\section{Part III. Quantitative and organisational aspects}

\section{Census information}

As noted, most early Irish Buddhists lived in Asia, and it is only in recent decades that significant numbers of Irish (or other) Buddhists can be identified in Ireland (Cox 2013: ch 6 ). The new situation reflects a radically changed world, in which post-colonial Ireland (since the 1990s) has experienced a new boom, while postwar Japan has become a leading economic power; new kinds of relationships have thus become possible.

However, between 1926 and 1991 the census did not collect information on "minor religions", while before and after these dates the numbers of Japanese individuals and of Buddhists were very small. Because dual Irish-Japanese citizenship is not normally possible, and with significant numbers of short-term Japanese residents on work postings, relatively few Japanese-born people are likely to have taken Irish citizenship (in the early $21^{\text {st }}$ century a Japanese Saturday school in Dublin sought to enable Irish-resident children of Japanese people to enter the Japanese education system later). Moreover, not all Japanese people are Buddhists, while Irish people identifying with Japanese Buddhist traditions are not distinguished in the census. Numbers, and the capacity to identify specifics, are even smaller for Northern Ireland.

In 1991, there were 596 "Asian or other" non-EU Buddhists in the Republic; in 2002 there were 1,897 and in 2006 3,562. Of the 2002 and 2006 figures about $90 \%$ of these were Asian. This can be cross-referenced with the numbers of migrants from Asian countries with significant Buddhist populations; in 2006 there were over 200 but under 1,000 Japanese people. This suggests at most a few hundred Buddhists with Japanese citizenship (Cox 2013: 352), but probably somewhat lower: in 2011 (with a significant overall increase in Buddhists albeit a slight dip in immigration) a total of 189 Japanese people identified as Buddhists; in 
2016 the figure was $246^{4}$. Adding Northern Ireland and Japanese-born people with Irish citizenship, we might estimate no more than 400 Japanese Buddhists on the island in 2020.

However a significant proportion of Ireland's convert Buddhists (whether Irish or of other nationalities) identify with specifically Japanese traditions. As we have seen, this is unlikely to characterise Irish Buddhists before the mid-twentieth century, with limited awareness of or access to distinct national traditions. From the 1970s onwards, Irish Buddhists had much greater contact with specific Asian Buddhisms. As Cox (2013) showed, a majority of convert Buddhists within Ireland today are still probably unaffiliated in formal terms; however, a broad identification with a particular Buddhist tradition (e.g. Theravada, Zen, Tibetan) is more common than previously.

The overall figures for Buddhists in the Republic are 986 in 1991 (Northern Ireland had another 270), 3894 in 2002 (NI 533 in 2001), 6516 in 2006, 8703 in 2011 (NI 1046) and 9358 in 2016. In the Republic about half of these are converts (not necessarily of Irish nationality). A reasonable estimate might be that $20-25 \%$ of these convert Buddhists primarily identify with specifically Japanese traditions, usually Soka Gakkai (SGI) or Zen, with others identifying with Theravada, other Mahayana and western traditions or with none.

Thus for 2020, with somewhat more than 10,000 Buddhists in Ireland north and south, we might find 1,000 - 1,250 convert Buddhists identifying with Japanese traditions as well as the 400 Japanese people who identify as Buddhist, for a total of perhaps 1,500 people identifying with Japanese Buddhist traditions. SGI-Ireland's figure of 550 self-identified members (below) for the Republic is broadly in line with this, and we might expect somewhat higher rates of organisational affiliation among those identifying with SGI by comparison with those identifying with Zen.

\section{Early routes to Ireland}

Following Nattier (1998), we can identify three different paths that Japanese Buddhism has travelled to Ireland: with Japanese immigrants, via Irish-based people travelling to Japan or otherwise seeking it out, and via missionaries from Japanese Buddhist organisations. Japanese Buddhist immigration dates back at least to the 1970s and has expanded since the late 1990s (Cox 2013: 328). Like most other migrant Buddhisms in Ireland, Japanese Buddhist migrants have not arrived in numbers requiring the construction of temples in Ireland. The Japanese Embassy were unable to speculate on the personal Buddhist practice of Japanese expatriates in Ireland.

As noted, Dublin has a Saturday school for Japanese children, where Buddhism is referred to during Japanese language class in the study of classics. Its Principal Saito Shoichi explains how words and concepts such as Shogyōmujō (Jp.諸行無常), 'the impermanence of worldly things,' Jōshahissī (Jp. 盛者必衰), ‘all things are subject to decay’ and Inngaōhō (Jp. 因果応 報), 'Karmic/ causal retribution', are taught at the school. Furthermore, the students sit in zazen each Saturday morning before classes.

When Irish people have directly sought out Buddhism in Japan, this has primarily been Zen. An early example is the Zen Meditation Group in Tallaght, founded by Dominican priest Philip McShane in the late 1970s after visiting Japan (Cox 2013: 317, 330). In its early years

\footnotetext{
${ }^{4}$ https://www.cso.ie/px/pxeirestat/Statire/SelectVarVal/Define.asp?maintable=E8059\&PLanguage=0
} 
it invited Soto Zen teachers from England's Throssel Hole monastery, while in the 1980s it moved towards Theravada insight meditation.

Also in the late 1970s, Irish-American Maura "Soshin" O'Halloran taught herself to meditate as a young woman in Dublin, before travelling to Japan to practice Soto Zen and receiving dharma transmission shortly before her accidental death in 1982. Her Zen journals, published as Pure Heart Enlightened Mind, have been an international best-seller (O'Halloran 1995).

\section{Expatriate Japanese Buddhists}

With the important exception of Soka Gakkai (below), the most striking feature of Japanese Buddhist groups in Ireland is the small number of native Japanese participants. This may in part represent difficulties in researching a relatively small population, but (as with most other Buddhisms in Ireland) there is no Japanese diaspora-dominated group in Ireland. In American Zen contexts, authors like Asai and Williams (2013) have noted tensions between migrant and convert Buddhists, but in Ireland we do not find these "parallel congregations" (Numrich 1999: 67).

Of course Japanese people in Ireland may in many cases not consider themselves "Buddhist" in a western sense, but simply be registered for a Buddhist funeral, practice occasional Pure Land recitations for traditional reasons or observe specific festivals, or practice individually or in family contexts at home with no institutional affiliation. Moreover, in the $21^{\text {st }}$ century if Japanese teachers like Shodo Harada Roshi can visit Ireland to teach, Irish people like the O'Hallorans can go to Japan for years at a time, Peter Rocca can teach Zen both in Tokyo and Ireland and Myozan Kodo can do dokusan by skype.

Native Japanese Buddhists living in Ireland may well engage with their own traditions of Buddhism in the same way; while Chinese and Malaysian people sometimes arrange funerals via Japanese groups like Zen Buddhism Ireland, who also perform namings and weddings, kito 祈祷 ceremonies and the mizuko kuyō 水子供養 “water child memorial service” for women who have lost children or had abortions ${ }^{5}$. In this way Japanese Buddhism is becoming part of family and community life.

\section{Soka Gakkai International}

Founded upon the Nichiren practice of reciting the Lotus Sūtra, Soka Gakkai International are by far the most widely practiced strain of Japanese Buddhism in Ireland with approximately 550 official members and 450 active members practicing in the Republic. SGI Northern Ireland (part of SGI UK) has approximately 100 members. SGI-Ireland began in 1978 when English teacher Máirín Ní Bhríain learned the practice from one of her Japanese students, Hiro Yoshii. In its early years it depended largely on Irish members, but since the 1990s it has been boosted by Japanese immigrants, several of whom now hold leadership positions (Cox 2013:354).

The organizational structure of SGI-Ireland divides the Republic into chapters and districts. As numbers grow, new districts can be created, each having at least one but usually multiple groups. Groups usually meet in private houses. At present there are nine chapters: Donegal and Monaghan (2 districts), Ireland East and Midlands (2), South County Dublin (4), Dublin

\footnotetext{
${ }^{5}$ Thanks to Myōzan Kōdō for this information.
} 
South Central (4), Dublin North (3), Dublin West (2), South East Ireland (2), South West Ireland (4), West of Ireland (2).

Chapter leaders try to meet in Dublin once per month, where the highest number of practitioners are. The Cork area (South West Ireland Chapter) was recently expanded to 4 districts and is the biggest growth area according to Sinéad Lynch, Women's Division Chapter Leader for Donegal and Monaghan. The internal structure of SGI consists of an adult women's division, a young women's division, an adult men's division and a young men's division. These divisions are reflected in the internal organization of the various chapters, groups and districts.

SGI is not only the biggest Japanese Buddhist-related organization in Ireland. It is also one of the most international: Irish people are a minority within the organization. During the research for this paper, a meeting of a group in Cork City was attended. With approximately 20 people in attendance, the customary chanting was led by a Japanese lady, reflecting the diversity of nationalities represented there and contrasting with the prevalence of western teachers in the Zen lineages.

\section{Zen groups in Ireland}

Probably the best-established Zen group is the Sōto group Zen In Ireland, affiliated to the Association Zen Internationale (1970) and La Gendronnière (1979) in the Loire Valley of France, founded by Deshimaru Taisen (Jp. 弟子丸 泰仙) (1914-1982). One of Deshimaru's students, Tainan Alain Liebmann (ordained 1976), brought his teacher's Sōtō Zen to Irish shores in 1991. Having received dharma transmission from Koshu Itabashi Zenji in both Sōjiji (Jp. 總持寺) and Eihei-ji (Jp. 永平寺), the two head temples of the Sōtō Order, in 2013, he left Ireland in 2014 after 25 years, having founded Zen groups in Cork, Dublin, Limerick and Galway.

Groups affiliated with Zen Ireland are Galway Zen Dojo (Dominick Street), Limerick (O’Connell Street), Dublin city's Earth and Sky Dojo (Gardiner Street Upper) and Ranelagh Zen Group. A Cork Zen Dojo affiliated with Zen Ireland (Liberty Street) seems to be inactive at time of writing, not to be confused with the still active Cork Zen Group (North Main Street), also founded by Alain Liebmann but which has since set an independent course.

The Galway Dojo, for example, hosts approximately 20 - 30 practitioners who come at different times. Approximately 6 people come consistently for morning practice and an average of 10 in the evenings. A special 'Zazen Day' is held once a month, attracting $8-15$ participants. Sesshins are held twice a year with an average of 20 participants. A recent sesshin in Athenry saw 45 people in attendance, half from different parts of Europe including Shojaku Françoise Lesage an ordained nun and teacher at Mauldre, France, and Keisen Vincent Vuillemin an ordained monk and teacher at Geneva Zen Dojo in Switzerland who taught alongside Jikai Tom Cleary.

Both Tom and his fellow teacher at Galway Zen Dojo, Mary Laheen, have spent time at Gotanjoji Temple, Fukui Prefecture, Japan as well as regular visits to La Gendronnière, France. Practitioners from Zen Ireland also attend Deshimaru retreats in Europe (Spain being a regular destination) as well as retreats in other lineages. In addition to the biannual sesshins run by Zen Ireland, Mary Laheen attends 3 to 4 sesshins per year in other Irish Zen schools and with the White Plum Asanga Zen School in the U.S., part of the Maezumi lineage.

There are two groups in the lineage of Shunryū Suzuki (Jp. 鈴木 俊隆) (1904-1971), the Sōtō Zen priest who founded the San Francisco Zen Centre. The Belfast Black Mountain Zen 
Centre (BMZC)'s resident teacher is Dublin born Rev. Myogan Djinn Gallagher who also resided at San Francisco Zen Centre from 2007 to 2016 under her Belfast-born teacher Ryushin Paul Haller, who visits Belfast from San Francisco twice a year to teach. Affiliated groups include the Coleraine and Newcastle Zen groups, also in Northern Ireland.

In County Clare, Ingen Breen runs a Zendo from his house, named in Japanese temple style by attaching the suffix ji (meaning 'temple') to his name. Ingen is also a Sōtō Zen priest in the lineage of Shunryū Suzuki, with ties to the San Francisco Zen Centre and their Tassajara Mountain Centre, having received Dharma Transmission in 2009 from Zoketsu Norman Fischer. He has led sesshin and retreats in Ireland, the U.K, Sweden, Italy, Russia and the U.S.

Zen Buddhism Ireland is a Sōtō Zen school under the guidance of Myozan Kodo Ian Kilroy, an Irish Sōtō Zen priest in the lineage of Nishijima Gudō Wafu Roshi

(Jp.西嶋愚道和夫)(1919-2014). Having practiced under Paul Haller of the San Francisco and Black Mountain Zen Centre for two years, Myozan Kodo sought out the lineage of Nishijima Roshi to deepen his practice Along with traditional face-to-face training and retreats, Myozan Kodo held weekly interviews with his Japan-based teacher on Skype over 5 years, receiving authorization to teach in 2014 and now ordaining priests in training in Ireland. The group are based at the Quakers' Meeting House on Eustace Street, Dublin and have a core group of approximately 20 practitioners with 10 less regular participants. Myozan Kodo is also President of the umbrella Irish Buddhist Union.

Peter Rocca is an Irish Zen Priest based in Japan, ordained in the lineage of Nishijima Gudo Wafu. As a guiding-teacher of the Dogen Zen Sangha, Peter teaches Zen in English in the centre of Tokyo and outside the city in temples such as Shōgaku-ji Temple (Jp. 正覚寺) in Saitama Prefecture. Peter also teaches Zen in the Galway area when he returns there on average once per year.

Ireland's only current Rinzai Zen meditation group is One Drop Zen, based on Heytesbury Street in central Dublin. They are affiliated with Sogenji Monastery near Okayama, Japan and a monastery near Hanover of the same name where members of the Irish group go regularly for week long sesshins. One Drop Zen also has monasteries in the U.S. and India. The group on Heytesbury Street hosts a core group with one Chinese person, one Italian and 3-4 Irish regulars. Beth O'Halloran, the sister of Soshin Maura O'Halloran, is a guiding teacher at One Drop Zen, having practiced Zen for over three decades and having herself trained for 3 years at the Sogenji Monastery in Japan (1995-1999) under Shodo Harada Roshi and visited the monastery regularly until 2003. Members of the Dublin group travel to Germany to practice with Shodo Harada Roshi.

Finally, the tradition of interfaith dialogue between Catholicism and Zen has also revived, with Zen practitioners like the Irish Jesuit Gavin T. Murphy. Besides Zen retreats held at the Dominican Seminary in Tallaght, Co. Dublin, Jesuit priest and Zen practitioner, Ama Samy SJ has also visited Dublin to teach Zen to his fellow Jesuits.

\section{Japanese martial arts in Ireland and Zen}

Since Nukariya Kaiten compared the unflinching courage, discipline and manliness of a Samurai to that of a Zen monk in his Religion of the Samurai (1913), Zen has been inextricably linked with Japanese Bushìdo (Jp. 武士道) in the minds of western martial artists. Most notable in Ireland is the zazen practice of Gyofukan Aikido Dojo on Pearse Street, Dublin, part of the Irish Aikido Federation. Here Sōtō Zen Shikantaza (Jp. 祗管打坐) 
is practiced in conjunction with the study of Dogen's 'A Universal Guide to the Right Way to Zazen.' While formal sitting is done sporadically at regular practice on weekdays, it is a central part of monthly weekend workshops, when practitioners sit formally in traditional style around the margins of the dojo facing the wall. A single sitting lasts for 1 hour broken up in the middle by walking-meditation. Federation members come from across Ireland once a year in August for a week long sesshin.

Apart from the obviously strong interest in Zazen amongst the Aikido community, one survey respondent, affiliated with the martial art of Genbukan Ninpo, asserted his awareness that the introspective elements of the art were based on Mikkyo (Jp. 密教), tantric elements found in the practices of the Shingon-shū (Jp. 真言宗).

\section{Shakuhachi music and Suizen}

Suizen (Jp. 吹禅)is the practice of 'blowing Zen', the signature practice of the Fuke-shu (Jp. 普 化宗), a Zen sub-sect whose monks played the shakuhachi (Jp.尺八) or traditional Japanese bamboo flute. The Fuke-shū continued a tradition in Zen of constructing 'a line of legitimation'(Deeg 2007: 9) when they were absorbed into existing denominations such as Rinzai. By the $19^{\text {th }}$ century 'there was a process of laicization, spiritualization and aesthetization of shakuhachi-playing, which consisted of an amalgamation of virtuous musical practice and Zen-Buddhist conceptions of spirituality'(Deeg 2007: 9). As with other Zen sects' claim to be a teaching outside the sutras, beyond words and speech, for the komusō (Jp.虚無僧) mendicants of the Fuke-shū this teaching beyond words was extended to music, held to express the ineffable quality of enlightenment. Thus, the practice of ichion jōbutsu (Jp. 一音成佛) or 'Attaining Buddhahood in a Single Note' was developed by the school.

Seikishi (Jp.聖騎士)('Holy Samurai’) Philip Horan has been playing Shakuhachi and practicing Suizen since 1996. Living in Dublin, he teaches the art of Shakuhachi and Suizen to students who often discover his school through an interest in Japan and Japanese martial arts. He spent two years in Japan from 1999-2001, studying the Tozan-ryu (Jp. 都山流) school of shakuhachi in Hiroshima. He later went on to do a Masters in Ethnomusicology focusing on shakuhachi acoustics and Japanese aesthetics. 'The Zen aspect of shakuhachi playing does not come into ensemble playing, but Zazen is often practiced before solo playing', according to Horan, who says that Suizen is a solitary practice. He is not a member of any formal Zen or Japanese Buddhist group. The west of Ireland was also home for a time to the renowned twentieth-century shakuhachi master, Araki Kodo V (b.1938)(荒木古童); his son is a traditional Irish music enthusiast.

\section{The condition of postmodernity}

Since the 1970s, Japanese Buddhist practice has arrived in Ireland via missionaries, immigrants and Irish people who have sought it out abroad. The declining equation between Irishness and Catholicism now makes it easier to be Irish, Buddhist and in Ireland. With Ireland's return to inclusion in a more global economy and the growth of cheap travel, the effort involved in travelling to Japan or bringing Japanese teachers to Ireland has lessened massively.

Japan's increasing global presence also means that the number of Japanese Buddhist traditions based in Europe or the US and/or operating through English has increased: Irish 
people have encountered Japanese Buddhism not only in Ireland or Japan but also in the U.K, Germany, France or San Francisco. The internet provides not only unlimited access to Japanese Buddhist texts such as the works of Dogen or Hakuin but also opens a real-time window into the Japanese temple compound, while practitioners like Myozan Kyodo can encounter their teacher via skype, further transforming the traditional geography of learning Buddhism. The coronavirus crisis has almost certainly accelerated this move to online Buddhist connections further, including between Irish practitioners.

New kinds of political encounter have developed: Japanese Buddhists have visited Ireland as Buddhist activists in peace-related contexts, notably in the context of shared opposition to nuclear weapons and campaigns for neutrality tied to US military presence at Okinawa and Shannon Airport. In the 1980s, the Irish Campaign for Nuclear Disarmament celebrated the Japanese practice of sailing lights down rivers (albeit typically on Hiroshima day), and planted cherry trees for similar reasons. Also in the early 1980s Japanese Buddhist monks on a peace pilgrimage protested against uranium mining plans in Donegal ${ }^{6}$ while in 2005 Rev. Gyosei Handa of the Nipponzan Myohoji "peace pagoda" in Milton Keynes, UK, was a regular in events supporting Catholic workers who had sabotaged US warplanes at Shannon airport (Cox 2013:367). ${ }^{7}$

\section{Conclusion}

As the world-systemic relationships that connect (or separate) Ireland and Japan have changed, so too has the transmission (or otherwise) of Japanese Buddhism. Early Irish knowledge, consisting mostly of ethnographic information mediated through capitalist trade and Christian missionary activity, was replaced as a channel - after the 'opening' of Japan and mass Irish emigration - by Irish people with direct experience of Japan like Charles Pfoundes, Lafcadio Hearn or Helen Waddell engaged more closely with Japanese Buddhism as practitioners, sympathisers and propagandisers, while a looser awareness became more widespread in Ireland itself.

In this period, the development of new kinds of nationalism defining themselves against British or European colonialism made it possible for Ireland and Japan, both on the fringes of their respective landmasses, to see themselves as culturally unique - and to do so in dialogue with one another. Japanese Buddhism, in the hands of Hearn, WB Yeats, DT Suzuki and others, provided a powerful language for this process, which took literary forms that still have powerful resonance today.

After Ireland's own mid-twentieth century religious closure, its participation in later twentieth century western counter cultures, a reviving global awareness and growing immigration have led to a third wave of encounter with Japanese Buddhism, this time involving far more Irish practitioners and a greater "bandwidth" of engagement - as well as Japanese Buddhists in Ireland.

This ties into the earlier history to ensure Japanese Buddhism a small, but significant, place in contemporary Irish society and culture. The full spectrum of Japanese Buddhist practices can

\footnotetext{
${ }^{6}$ http://revpatrickcomerford.blogspot.com/2010_02_27_archive.html

${ }^{7}$ http://www.indymedia.ie/article/83925?author_name=robbie\&condense_comments=false
} 
now be found in Ireland, from Nichiren, Sōtō and Rinzai to Suizen, hints of esoteric Shingon and personal Pure Land practice within the Japanese community.

There is no single history of Japanese Buddhism in Ireland, rather a series of encounters shaped by these changing historical contexts, the diversity of Japanese Buddhisms and the complex meanings of "global Buddhism". 


\section{Bibliography}

Asai, Senryo, \& Williams, Duncan Ryūken (2013). "Japanese American Zen temples". In American Buddhism (pp. 58-73). Routledge.

Bannister, Gary (2018). A Path Home/ Conair Siar. New Island Books.

Baumann, Martin. (2001). “Global Buddhism”. Journal of Global Buddhism, 2, 1-43.

Benesch, Oleg (2014) Inventing the Way of the Samurai: Nationalism, Internationalism, and Bushidō in Modern Japan. Oxford.

Bluck, Robert (2006). British Buddhism: Teachings, practice and development. Routledge.

Bocking, Brian, Cox, Laurence and Yoshinaga Shin'ichi (2014), “The first Buddhist mission to the West" DISKUS 16.3: 1 - 33.

Burleigh, David (ed., 2005). Helen Waddell's writings from Japan. Dublin / Portland: Irish Academic Press.

Buswell Jr, Robert E. (2005). Currents and countercurrents. University of Hawaii Press.

Campbell, Julian (2008). 'Introduction', 1-8, in Tim Goulding, Floating World. Dublin: Taylor Galleries.

Cott, Jonathan (1991). Wandering Ghost. New York: Knopf.

Cox, Laurence \& Griffin, Maria. (2009). "Border country dharma”. Journal of Global Buddhism, 10, 93-125.

Cox, Laurence (2013). Buddhism and Ireland. Sheffield: Equinox.

Cox, Laurence (2014). “Buddhism in Ireland”, Etudes irlandaises 39/2: 161 - 172.

Deeg, Max. (2007). "Komusō and 'Shakuhachi-Zen'”. Japanese Religions, 32, 07-38.

Denvir, Gearóid. (1988). “Continuing the Link”. The Irish Review (1986-), (3), 40-54.

Doherty, Gerald (1983). 'The World that Shines and Sounds'. Irish Renaissance Annual, vol. 4: 57-75.

Enomiya-Lassalle, Hugo-Makibi (1973). Méditation Zen et prière chrétienne. Éditions du Cerf, Paris.

Faure, Bernard. (1993). Chan insights and oversights. Princeton University Press.

Fujikawa, Mayu (2017). "Studies on the Jesuit Japan Mission”. Jesuit Historiography Online, doi: http://dx.doi.org/10.1163/2468-7723_jho_COM_196472.

Gierek, Bozena (2011). 'Celtic Spirituality in Contemporary Ireland', 301-16, in Olivia Cosgrove et al. (eds), Ireland's New Religious Movements. Newcastle: Cambridge Scholars.

Guinness, Selina (2004). "Ireland through the stereoscope." 19 - 33 in Betsey FitzSimon and James Murphy (eds.), The Irish revival reappraised. Dublin: Four Courts.

Hall, Thomas (2000). "World-systems analysis". 3-28 in Hall (ed), A World-Systems Reader. Boulder, CO: Rowman and Littlefield.

Hayley, Barbara (1988). "Lafcadio Hearn, W. B. Yeats and Japan.” Literature and the Creation of Art. Gerrards Cross, UK: Colin Smythe. 
Heaney, Séamus (2000) in Ohno, M. et al,. "Hokusai, Basho, Zen and More". Journal of Irish Studies, 15-31.

"An Irish Gael" (1926). "How I found Buddhism" 6-8 in The British Buddhist.

Ives, Colta Feller. (1974). The great wave. Metropolitan Museum of Art.

Johnston, William. (1997). Christian Zen. Fordham Univ Press.

Nukariya, Kaiten. (2005). The religion of the samurai. Cosimo, Inc.

Lennon, Joseph (2003). Irish Orientalism. Syracuse: Syracuse UP.

McCormack, William John. (1985). Ascendancy and tradition in Anglo-Irish literary history from 1789 to 1939. Oxford University Press, USA.

Meyer, Kuno. (Ed.). (1911). Selections from ancient Irish poetry. Constable Limited.

Murray, Paul (1993). A fantastic journey. Folkestone: Japan Library / Curzon.

Nattier, Jan (1998). 'Who Is a Buddhist?' 183-95 in Charles Prebish and Kenneth Tanaka (eds), The Faces of Buddhism in America. Berkeley, CA: University of California Press.

Numrich, Paul David. (1999). Old wisdom in the new world. Univ. of Tennessee Press.

O’Halloran, Maura (1995). Pure Heart, Enlightened Mind. London: Thorsons.

O’Leary, Joseph (1999). 'Religious Pluralism and Christian Truth', 239-41, in BuddhistChristian Studies (19/1).

Offermans, Jürgen (2005). "Debates on atheism, quietism and sodomy". Journal of Global Buddhism 6: 16 - 35.

Polo, Marco (1968). The travels of Marco Polo. London: Folio.

Rexroth, Kenneth (ed., 1977). The Buddhist writings of Lafcadio Hearn. Santa Barbara: Ross-Erikson.

Rocha, Cristina (2006). Zen in Brazil. Honolulu: University of Hawai'i Press.

Rosenstock, Gabriel (2014). Chogyam Trungpa. Nihon kokusai shijin kyokai (Japan Universal Poets Association).

Shiro, Naito (1972). 'Yeats and Zen Buddhism'. The Eastern Buddhist, 5/2: 171-78.

Sims-Williams, Patrick. (1996). The invention of Celtic nature poetry. Celticism, 8, 97.

Siung, J. (2001). The Influence of Japanese Art on Twentieth Century Irish Art (Doctoral dissertation, University College Dublin).

Sproule, John (1854). The Irish Industrial Exhibition of 1853. Dublin: McGlashan.

Suhr-Sytsma, Nathan (2010). Haiku Aesthetics and Grassroots Internationalization. ÉireIreland, 45(3), 245-277.

Suzuki, D. T. (1959). Zen and Japanese culture. Princeton: Princeton University Press

Turner, Alicia, Cox, Laurence and Brian Bocking, The Irish Buddhist. New York: Oxford University Press, 2020.

Tweed, Thomas (2000). The American encounter with Buddhism 1844 - 1912. Chapel Hill: UNC Press

Vu Thanh, Hélène (2017). "The Glorious Martyrdom of the Cross". Culture and History Digital Journal, vol. 6 no. 1. 
Wallace, Pat (2009). 'Welcome and Opening Remarks'. Paper to 'Asian Art and Ireland' Conference, National Museum of Ireland (November).

Yeats, William Butler (1926). Late poems. London: Macmillan 